\title{
Age, growth, mortality, and recruitment of thin sharpbelly Toxabramis swinhonis Günther, 1873 in three shallow lakes along the middle and lower reaches of the Yangtze River basin, China
}

\author{
Xianghong Dong ${ }^{1,2,3}$ ， Tao Xiang ${ }^{1,2}$ ， Tao Ju ${ }^{4}$, Ruojing Li ${ }^{1,2}$, Shaowen Ye ${ }^{1}$, Sovan Lek ${ }^{3}$, Jiashou Liu ${ }^{\text {Corresp., }}{ }^{1}$, \\ Gaël Grenouillet \\ 1 State Key Laboratory of Freshwater Ecology and Biotechnology, Institute of Hydrobiology, Chinese Academy of Sciences, Wuhan, China \\ 2 University of Chinese Academy of Sciences, Beijing, China \\ 3 Laboratoire Evolution \& Diversité Biologique, Université Toulouse III, Toulouse, France \\ 4 Key Laboratory of Freshwater Biodiversity Conservation, Ministry of Agriculture of China, Yangtze River Fisheries Research Institute, Chinese Academy of \\ Fishery Science, Wuhan, China \\ Corresponding Author: Jiashou Liu \\ Email address: jsliu@ihb.ac.cn
}

Despite being the most dominant and widespread small fish species in the lakes along the middle and lower reaches of the Yangtze River basin, Toxabramis swinhonis has been paid little attention by fisheries scientists and little is known about its population characteristics. For this reason, we estimated age, growth, mortality and recruitment of this species based on three shallow lakes, Biandantang Lake, Shengjin Lake and Kuilei Lake (BDT, SJH, and KLH, respectively) in this region. A total of 13585 (8818 in BDT, 2207 in SJH and 2560 in KLH) individuals were collected during monthly sampling from July 2016 to September 2017. The results revealed that the age structures of $T$. swinhonis consisted of four age groups $\left(0^{+}-3^{+}\right)$, with $0^{+}-1^{+}$year old fish comprising more than $98 \%$ of the samples. Allometric growth patterns were displayed by fish from all sampling sites and the von Bertalanffy growth functions (VBGM) estimated were $L_{t}=173.25\left(1-\mathrm{e}^{-1.20(t+1.09)}\right)$ : BDT; $L_{\mathrm{t}}=162.75\left(1-\mathrm{e}^{-1.20(\mathrm{t}+1.08)}\right): \mathrm{SJH} ;$ and $L_{\mathrm{t}}=215.25\left(1-\mathrm{e}^{-1.20(\mathrm{t}+1.12)}\right): \mathrm{KLH}$, respectively. The rates of total mortality $(Z)$, natural mortality $(M)$ and fishing mortality $(F)$ at BDT, SJH and KLH were computed as 5.82, 5.50 and 4.55 year $^{-1} ; 1.89,1.87$ and 1.75 year $^{-1} ; 3.93,3.63$ and 2.80 year $^{-1}$, respectively. Meanwhile, growth performance indices ( ) were 0.68 (in BDT), 0.66 (in SJH) and 0.62 (in $\mathrm{KLH}$ ), which indicated that $T$. swinhonis were overfished slightly in all study areas. Area-specific recruitment patterns were similar to each other, displaying evidence of batch spawning, with major peaks in April and August, accounting for $92.21 \%(B D T), 88.21 \%(\mathrm{SJH})$ and $88.73 \%(\mathrm{KLH})$ of total recruitment, respectively. These results showed that brief generation-time, fast growth rate, relatively high natural mortality rate and strong reproductive capacity ( $r$-strategies) are reasons why this species 
became the most dominant species in many lakes of China. 
1 Age, growth, mortality, and recruitment of thin sharpbelly Toxabramis swinhonis Günther,

21873 in three shallow lakes along the middle and lower reaches of the Yangtze River basin,

\section{China}

4 Xianghong Dong ${ }^{1,2,3}$, Tao Xiang ${ }^{1,2}$, Tao $\mathrm{Ju}^{4}$, Ruojing $\mathrm{Li}^{1,2}$, Shaowen $\mathrm{Ye}^{1}$, Sovan Lek ${ }^{3}$, Jiashou

5 Liu $^{1, *}$, Gaël Grenouillet ${ }^{3}$

$6{ }^{1}$ State Key Laboratory of Freshwater Ecology and Biotechnology, Institute of Hydrobiology,

7 Chinese Academy of Sciences, Wuhan, China

$8 \quad{ }^{2}$ University of Chinese Academy of Sciences, Beijing, China

$9 \quad{ }^{3}$ Laboratoire Evolution \& Diversité Biologique, Université Toulouse III, Toulouse, France

$1{ }^{4}$ Key Laboratory of Freshwater Biodiversity Conservation, Ministry of Agriculture of China,

11 Yangtze River Fisheries Research Institute, Chinese Academy of Fishery Science, Wuhan, China

$13 *$ Corresponding author:

14 Jiashou Liu

15 E-mail address: jsliu@,ihb.ac.cn 


\section{ABSTRACT}

Despite being the most dominant and widespread small fish species in the lakes along the middle and lower reaches of the Yangtze River basin, Toxabramis swinhonis has been paid little attention by fisheries scientists and little is known about its population characteristics. For this reason, we estimated age, growth, mortality and recruitment of this species based on three shallow lakes, Biandantang Lake, Shengjin Lake and Kuilei Lake (BDT, SJH, and KLH, respectively) in this region. A total of 13585 (8818 in BDT, 2207 in SJH and 2560 in KLH) individuals were collected during monthly sampling from July 2016 to September 2017. The results revealed that the age structures of $T$. swinhonis consisted of four age groups $\left(0^{+}-3^{+}\right)$, with $0^{+}-1^{+}$year old fish comprising more than $98 \%$ of the samples. Allometric growth patterns were displayed by fish from all sampling sites and the von Bertalanffy growth functions (VBGM) estimated were $L_{\mathrm{t}}=173.25\left(1-\mathrm{e}^{-1.20(\mathrm{t}+1.09)}\right)$ : BDT; $L_{\mathrm{t}}=162.75\left(1-\mathrm{e}^{-1.20(\mathrm{t}+1.08)}\right)$ : $\mathrm{SJH}$; and $L_{\mathrm{t}}=$ $215.25\left(1-\mathrm{e}^{-1.20(\mathrm{t}+1.12)}\right): \mathrm{KLH}$, respectively. The rates of total mortality $(Z)$, natural mortality $(M)$ and fishing mortality $(F)$ at BDT, SJH and KLH were computed as 5.82, 5.50 and 4.55 year $^{-1}$; 1.89, 1.87 and 1.75 year $^{-1} ; 3.93,3.63$ and 2.80 year $^{-1}$, respectively. Meanwhile, growth performance indices $\left(\phi^{\prime}\right)$ were 0.68 (in BDT), 0.66 (in SJH) and 0.62 (in KLH), which indicated that $T$. swinhonis were overfished slightly in all study areas. Area-specific recruitment patterns were similar to each other, displaying evidence of batch spawning, with major peaks in April and August, accounting for $92.21 \%(\mathrm{BDT}), 88.21 \%(\mathrm{SJH})$ and $88.73 \%(\mathrm{KLH})$ of total recruitment, respectively. These results showed that brief generation-time, fast growth rate, relatively high natural mortality rate and strong reproductive capacity ( $r$-strategies) are reasons why this species 
43 became the most dominant species in many lakes of China.

\section{INTRODUCTION}

Many lakes (about 4000) distributed along the middle and lower reaches of the Yangtze River basin (China) account for approximately $1 / 3$ of the total area of lakes in China ( Liu \& He, 1992; $L i, 2004$ ). These lakes are typically shallow (no thermal stratification) with numerous submerged aquatic macrophytes and generally have higher fisheries productivity ( $\mathrm{Li}$ et al., 2010; Ye et al., 2014). However, due to intensive removal of piscivores and overfishing by commercial fisheries in the past decades, short-lived small fish such as Hyporhamphus intermedius (Cantor, 1842), Hemiculter leucisculus (Basilewsky, 1855) Coilia ectenes taihuensis (Yen et Lin, 1976), Cultrichthys erythropterus (Basilewsky, 1855), Pseudobrama simoni (Bleeker, 1864) and Toxabramis swinhonis Günther, 1873 gradually become dominant species in these lakes and account for about 2/3 of total species (40-70 species in one lake) (Li et al., 1988; Cao et al., 1991; Liu et al., 2005; Mao et al., 2011; Ye et al., 2014). T. swinhonis was the most dominant of these species, accounting for more than $85 \%$ of total individuals caught in some lakes (Ge et al., 2009) and showing an increase trend in abundance (Li et al., 2018), which elevated our concerns on the sustainability of fisheries resources in these water bodies. and fisheries management as it is one of the main bycatch species in China's freshwater fishery, an important potential food resource for the carnivorous aquatic organisms (Dai et al., 2015; Ye et al., 2014), and plays a key role in the energy flows of their living hydro-ecosystems, 
64 linking zooplankton (as T. swinhonis mainly feeds upon copepods, cladocerans and insect larvaes)

65 to higher trophic levels (Zhang, 2005). Meanwhile, many fisheries scientists pointed out that

66 there existed a close relationship between population expansion and particular features of

67 biology and ecology (Peter, 1980; Wang et al., 2013; Guo et al., 2016). Thus, it is the time that

68

69 much more attentions should be paid on the biology and ecology of this outbreak species.

Published information on the biology and ecology of T. swinhonis is scarce. Li et al. (1988) defined this species as a small coarse fish and speculated on population control methods based on two reservoirs in northern China. Xie et al. (2001a and 2001b) investigated the relationship between diet and morphology of this species and also examined the association of submerged macrophytes in Liangzi Lake, China to density and biomass of this species. Ye et al. (2014) studied the growth and mortality of this species using length-based approaches in Niushan Lake, China.

In order to better understand the biology and ecology of this species and explain why it has become the most dominant fish species in many freshwater lakes of China, we conducted the present study to: (a) provide novel and comprehensive population characteristics of T. swinhonis, especially age structure (first report in the study regions), (b) identify demographic characteristics consistent with rapid population expansion, and (c) provide potential strategies for fishery management on $T$. swinhonis.

MATERIALS AND METHODS

\section{Study sites}


85 The present study was performed in three shallow lakes (no thermal stratification), Biandantang

86 Lake (BDT) $\left(114^{\circ} 43^{\prime} \mathrm{E}, 30^{\circ} 15^{\prime} \mathrm{N}\right)$, Shengjin Lake (SJH) $\left(117^{\circ} 03^{\prime} \mathrm{E}, 30^{\circ} 23^{\prime} \mathrm{N}\right)$ and Kuilei Lake

$87(\mathrm{KLH})\left(120^{\circ} 51^{\prime} \mathrm{E}, 31^{\circ} 24^{\prime} \mathrm{N}\right)$, along the middle and lower reaches of the Yangtze River basin,

China. These lakes are scattered longitudinally in this region. BDT, SJH and KLH are upstream, midstream and downstream, respectively (Fig. 1).

\section{Data collection and fish sampling}

Toxabramis swinhonis were collected monthly from July 2016 to September 2017 using multimesh gillnets $(1.5 \times 30 \mathrm{~m})$ (Appelberg et al., 1995). In order to obtain sufficient samples, sampling time in each lake was at least three days monthly. In addition, larval and juvenile $T$. swinhonis were caught by fishermen using electrofishing gear to ensure a representative and unbiased assessment of their biological characteristics. Total lengths (L) were measured to nearest $0.01 \mathrm{~mm}$ with a vernier calliper and body weights (W) were recorded to the nearest 0.01 $\mathrm{g}$ with a precision balance in the field. Sex was determined macroscopically. Scales were removed randomly from the middle portion of the lateral body of 30 individuals per month from each site and stored in small envelopes labelled with sampling site and morphometric data

(Narejo et al., 2009; Zhang \& Li, 2002). Lake surface temperatures (LST) were recorded every four hours throughout the study period using HOBO Temp/Light data loggers (start time 8 am)

(Da, 2015; Dalton et al., 2016). All the procedures described here were approved by the ethics committee of the Institute of Hydrobiology, Chinese Academy of Sciences (Y216011101). 
106

107

108

109

110

111

112

113

114

115

116

117

118

119

120

121

122

123

124

125

126

\section{Length distribution and length-weight relationship}

Kolmogorov-Smirnov tests (K-S tests) were used to evaluate the similarity of length-frequency distribution between different sampling sites and normality of data. Differences in mean L of $T$. swinhonis among sites were evaluated using Kruskal-Wallis test with Tukey's post-hoc when the error or data wasn't a normal distribution. The relationship between length and weight was calculated for each site using power regression equation:

$$
W=a \mathrm{~L}^{b} \mathrm{e}^{\varepsilon}, \varepsilon \sim \mathrm{N}\left(0, \sigma^{2}\right),
$$

where $a$ is the intercept of the regression or shape coefficient and $b$ is the allometric or slope parameter (Ricker, 1975). The optimal regression parameters were gained by minimizing the residuals errors using the ordinary least square (OLS) method (O'Brien, 2012). Student's $t$-test was utilized to test whether the slope of regression was significantly different from 3 , indicating the growth pattern of fish: isometric ( $b=3$, no change of density and shape as one fish grows), positive allometric $(b>3$, the fish becomes relatively stouter or deeper-bodies as it becomes longer) or negative allometric ( $b<3$, fish becomes slimmer as it grows) (Ye et al., 2007). Generally, the allometric coefficient $(b)$ is within the range from 2 to 4 for most fish species (Koutrakis \& Tsikliras, 2003), and thus this thumb rule can be used to corroborate the validation of the length and weight relationships of $T$. swinhonis in our study. All statistical analyses were performed using R software version 3.3.2 (R Core Team, 2017) with significance level ( $\alpha$ ) equal to 0.05 .

\section{Growth}


127 Growth of a fish can be described as an increase in either length or weight. Several mathematical

128 equations have been created to model fish growth. One of these, the von Bertalanffy growth 129 model (VBGM) is widely used to model growth of fishes. Thus, we used the VBGM to describe 130 the growth of $T$. swinhonis in the current study. The typical VBGM is represented by (Von 131 Bertalanffy, 1938):

where $L_{t}$ is the expected or average $\mathrm{L}$ at time (or age) $t, L_{\infty}$ is the mean asymptotic $\mathrm{L}, K$ is the rate at which $L_{\infty}$ is approached, and $t_{0}$ is the hypothetical age at which fish $\mathrm{L}$ equals zero. While

VBGM parameters can be estimated by length (weight)-age approach, the length-based method is most extensively adopted, especially in the tropical and subtropical regions (Sparre \& Venema, 1998). In this study, length-frequency datasets with a constant class size (5 mm) were used to obtain the optimal growth parameters (corresponding to the maximum of the goodness of fit index, $R_{n}$ ) using the FiSAT II software (Gayanilo et al., 2005) and the module of ELEFAN I

(Pauly, 1986). The theoretical age $\left(t_{0}\right)$ was determined by the empirical equation of Pauly (1983):

$$
\log _{10}\left(-t_{0}\right)=-0.392-0.275 \log _{10}\left(L_{\infty}\right)-1.038 \log _{10}(K)
$$

In order to compare the growth performance of different geographical populations, the growth performance index (GPI) $\phi^{\prime}$ (phi-prime) was calculated using the following formula (Pauly \&

Munro, 1984):

$$
\phi^{\prime}=\log _{10}(K)+2 \log _{10}\left(L_{\infty}\right)
$$




$$
t_{\max }=\frac{3}{K}
$$

where $t_{\max }$ is the approximate maximum age of $T$. swinhonis at each study site, and $K$ is the growth constant in von Bertalanffy growth function.

\section{Age estimate}

Scales of $T$. swinhonis were immersed in $10 \% \mathrm{NaOH}$ solution for three hours, cleaned with running water and examined under a dissecting microscope to determine age (Steinmetz \& Müller, 1991). Four to six scales were examined from each fish, and age was eventually defined as the most frequently occurring age from the scales.

\section{Mortality coefficients and fisheries status}

To obtain the total mortality rates $(Z)$, the length-converted catch curves were applied to the pooled length frequency datasets using the estimated growth parameters. This process was done using the FiSAT II package and mortality menu (Gayanilo et al., 2005).

The natural mortality rates (M) were obtained from Pauly's (1980) empirical equation:

$$
\log _{10} M=-0.0066-0.279 \log _{10} L_{\infty}+0.6543 \log _{10} K+0.4634 \log _{10} T
$$

where $T$ is the average annual LST $\left({ }^{\circ} \mathrm{C}\right.$ ) (in the present study, along the direction of increase of longitude, $T=17.5,16.6$ and $17.1^{\circ} \mathrm{C}$, respectively), a proxy for the habitat temperature (Pauly, 1980). The validity of estimates of $M$ can be judged by the $M / K$ ratio as this ratio has been demonstrated to be within the range of 1.12-2.50 for most species around the world (Beverton \& 
169

170

171

172

173

174

175

176

177

178

179

180

181

182

183

184

185

186

187

188

189

Fishing mortality $(F)$ was estimated from the equation $F=Z-M($ Gulland, 1965).

We estimated exploitation rate $(E)$ using the equation of Elliott (1983):

$$
E=\frac{F}{Z} \text {. }
$$

\section{Recruitment time and pattern}

Timing and patterns of recruitment to $T$. swinhonis stocks were determined by backward projection of the length-frequency datasets onto the time axis of a time-series of samples as described in FiSAT II (Moreau \& Cuende, 1991). This routine can provide the relative spawning time and the number of recruitment pulses (recruitment pattern) per year.

\section{RESULTS}

\section{Length-frequency distribution and age structure}

A total of 13585 individual T. swinhonis were measured during 15 months of field sampling. The length-frequency distributions of $T$. swinhonis are shown in Fig. 2. Lengths of $T$. swinhonis ranged from 53.32 to $165.16 \mathrm{~mm} \mathrm{~L}$ (mostly between $60-140 \mathrm{~mm}$ ) in BDT, from 51.39 to 154.35

mm (mostly between $80-140 \mathrm{~mm}$ ) in $\mathrm{SJH}$ and from 61.94 to $198.85 \mathrm{~mm}$ (mostly between 100 $180 \mathrm{~mm}$ ) in KLH. Results from K-S tests indicated that length frequency distribution data were non-normal in three lakes (for all three K-S tests, $\left.D=1, P \approx 0\left(<2.2 \times 10^{-16}\right), E=1\right)$. Individual comparisons of these distributions indicated statistical differences between lakes (for BDT and $\mathrm{SJH}, D=0.43, P \approx 0\left(<2.2 \times 10^{-16}\right), E=0.43$; for BDT and KLH, $D=0.75, P \approx 0\left(<2.2 \times 10^{-16}\right)$, $E=0.75 ;$ and for SJH and $\left.\mathrm{KLH}, D=0.56, P \approx 0\left(<2.2 \times 10^{-16}\right), E=0.56\right)$. Kruskal-Wallis test ( 
$\left.190 \chi^{2}=5186.90, d f=2, P \approx 0\left(<2.2 \times 10^{-16}\right), E=0.28\right)$ revealed that there was a statistical

191 difference in mean $\mathrm{L}$ among different sampling sites and represented a trend of $\mathrm{L}$ increasing with

192 the increasing longitude (Fig. 3).

193 Age structure of the T. swinhonis specimens collected from the three lakes, as determined 194 from scales, were simple and consisted of four age groups ranging from $0^{+}-3^{+}$years (Fig. 4), 195 similar to results obtained using Pauly's (1983) empirical equation for maximum age $\left(t_{\max }=3 / \mathrm{K}\right.$, 196 all sites were 2.5$)$. The dominant age group was $0^{+}-1^{+}$year old fish at all three sites (98\%) (Table

197

198 199

200

201

202

203

204

205

206

207

208

209

210

1). These data suggest that $T$. swinhonis is a short-lived fish species. A chi-square test found significant differences among the age structures at the three sampling sites $\left(\chi^{2}=103.82, d f=6\right.$, $\left.P=4.00 \times 10^{-20}, E=0.18\right)$.

\section{The length-weight relationships and growth pattern}

$\mathrm{L}$ and $\mathrm{W}$ relationships for each site (sexes combined) were (Fig. 5):

BDT: $W=0.000008 \mathrm{~L}^{2.906}, R^{2}=0.87, n=8818$;

SJH: $W=0.00002 \mathrm{~L}^{2.734}, R^{2}=0.87, n=2207$;

KLH: $W=0.0000001 \mathrm{~L}^{3.775}, R^{2}=0.89, n=2560$.

There were significant differences obtained from the statistical comparisons of total length and weight relationships among different sites (for BDT and SJH, $F=58960, d f_{1}=1, d f_{2}=8816, P \approx$ $0\left(<2.2 \times 10^{-16}\right), E=0.87$; for BDT and KLH, $F=15800, d f_{1}=1, d f_{2}=2205, P \approx 0\left(<2.2 \times 10^{-}\right.$ $\left.{ }^{16}\right), E=0.87$; and for SJH and $\mathrm{KLH}, F=19870, d f_{1}=1, d f_{2}=2558, P \approx 0\left(<2.2 \times 10^{-16}\right), E=$ 0.89). All slope coefficients ( $b$ values) were significantly different from the value of 3 for all 
211 three lakes (for BDT, $t=-7.84, d f=8816, P=5.15 \times 10^{-15}, E=0.08$; for SJH, $t=-12.22, d f=$

$2122205, P=2.74 \times 10^{-33}, E=0.26$; and for $\left.\mathrm{KLH}, t=28.93, d f=2558, P=1.74 \times 10^{-159}, E=0.57\right)$,

213 indicating an allometric growth pattern of $T$. swinhonis for all sampling populations.

214

215 Growth parameters

216 Since the age structure of $T$. swinhonis was simple, we estimated growth parameters using the 217 methods of Powell and Wetherall, which are contained in the ELEFAN I module of the FiSAT II 218 program. The results were BDT: $L_{\infty}=173.25 \mathrm{~mm}, K=1.20, t_{0}=-1.09, R_{\mathrm{n}}=0.21 ; \mathrm{SJH}: L_{\infty}=$ $219162.75 \mathrm{~mm}, K=1.20, t_{0}=-1.08, R_{\mathrm{n}}=0.29 ; \mathrm{KLH}: L_{\infty}=215.25 \mathrm{~mm}, K=1.20, t_{0}=-1.12, R_{\mathrm{n}}=$ 220 0.24. The growth equations obtained above showed that $T$. swinhonis grew rapidly during the first year of it's life history, obtaining an average L of approximately 159.14, 149.34 and 198.34 $\mathrm{mm}$ with the increase of longitude during the first year, respectively, for BDT, SJH and KLH (more than $90 \%$ of $L_{\infty}$ at all sites). Annual growth in $\mathrm{L}$ decreased sharply after this period and became relatively constant thereafter (Fig. 6). In addition, the growth performance index ( $\left.\phi^{\prime}\right)$ of T. swinhonis in BDT, SJH and KLH were 4.56, 4.52 and 4.75, respectively.

Mortality and exploitation rates

The total rates of mortality $(Z)$ obtained through the length-converted catch curves were 5.82 year-1 $^{-1}$ (with 95\% confidence interval of Z: 3.29-8.36 year-1) for BDT, 5.50 year $^{-1}$ (with 95\% confidence interval of $Z$ : 3.31-7.70 year ${ }^{-1}$ ) for $\mathrm{SJH}$ and 4.55 year $^{-1}$ (with $95 \%$ confidence interval 
232 by Pauly's (1980) empirical equation were 1.89 year $^{-1}$ (BDT), 1.87 year $^{-1}(\mathrm{SJH})$ and 1.75 year $^{-1}$ $233(\mathrm{KLH})$, respectively. For BDT, SJH, and $\mathrm{KLH}$, the values of $M / K$ ratio were $1.58,1.56$ and 1.46

234 and the fishing mortality rates $(F)$ were $3.93,3.63$ and 2.80 year $^{-1}$, respectively. The exploitation 235 rates $(E)$ for three sampling populations of $T$. swinhonis were calculated as 0.68 (BDT), 0.66 $236(\mathrm{SJH})$ and $0.62(\mathrm{KLH})$ year $^{-1}$, respectively, which indicated that the stocks in the present study 237 areas have been overfished slightly.

\section{Recruitment time and pattern}

Recruitment time and pattern of $T$. swinhonis were similar at all sampling sites. The recruitment

pattern was continuous and showed two major peaks throughout the year (Fig. 8), which indicated batch spawning by T. swinhonis. Recruitment occurred from March to September with peaks in April and August. These two peaks accounted for 92.21\% (BDT), 88.21\% (SJH) and $88.73 \%(\mathrm{KLH})$ of total recruitment, respectively.

\section{DISCUSSION}

\section{Size and distribution of length}

248 Knowledge about size structure would be used for understanding age, growth, recruitment and dynamics of the population, which varies with the size structure of the population (Mirzaei et al., 2014). Generally, the size structure of one fish species can be represented by the length- 
253

254

255

256

257

258

259

260

261

262

263

264

265

266

267

268

269

270

271

272 273

majority in $80-140 \mathrm{~mm}$ ) and in KLH from 61.94 to $198.85 \mathrm{~mm}$ (the majority in $100-180 \mathrm{~mm}$ ), and represented an increasing trend in L with increasing longitude. The Kolmogorov-Smirnov tests indicated that length frequencies for $T$. swinhonis were non-normally distributed at all sites and that there were statistical differences between all sites. Besides, the results obtained from the present study were much larger than the findings of all previous works (Table 2). The disparity observed in the size of $T$. swinhonis in different studies might be caused by one or more of the following elements: (1) differences of habitat (such as the temperature, density of food and food availability); (2) sample size differences; (3) differences in gear selectivities between studies; and (4) differences in the genetic diversity of different geographical populations.

\section{Length-weight relationship and growth pattern}

The length-weight (L-W) relationship of a fish species always been considered as fundamental to further study, such as fish stock assessment (Afrooz et al., 2014). Generally, this relationship is used by freshwater ecologists and fisheries managers for (1) predicting the weight (length) for a given length (weight); (2) describing the fitness condition or morphology of one fish species; (3) estimating growth, age structure and many other aspects of a species' population dynamics; and (4) mutual transformation between length and weight for many stock assessment models (Cren, 1951; Ye et al., 2007). Though some fisheries scientists thought it has little value (Hilborn \& Walters, 1992), Froese (2006) pointed out that a comprehensive analysis of this relationship of a large number of geographic populations can provide important insights into the biology and ecology of that species. 
present study were 2.91 (in BDT), 2.73 (in SJH) and 3.78 (in KLH), respectively. Fish at all the spatial similarity of the sampling sites in these studies. the difference of habitat (especially the observed temperature), the sample size used, diseases and genetic diversity (Wootton, 1998; Ye et al., 2007).

\section{Age structure and growth parameters}

Generally, information about age structure and growth parameter of a fish population would be used for fish stock assessment (Hollyman, 2017; Wells et al., 2013), which allows fisheries scientists and managers to understand the dynamics of fish stock and how fish populations respond to the environmental changes. More specifically, it can be an indicator of fish population dynamics and help managers make more informed choices for fish conservation and fisheries 
295 In view of this, we first presented the age structure of $T$. swinhonis in the middle and lower 296 reaches of the Yangtze River basin based on scale readings and Pauly's empirical equation. 297 These results showed that the age structure of $T$. swinhonis was very simple and dominant ages

were $0^{+}-1^{+}$year old fish (more than $98 \%$ at all sites in the present study) which corresponded well with the previous work in the two reservoirs of northern China (Li et al., 1988). The short lifespan of T. swinhonis is very similar with Pseudorasbora parva (Temminck et Schlegel, 1842) and H. leucisculus (two other small dominant species in this region), whose lifespan are no more than 5 and 6 years, respectively (Gozlan et al., 2010; Wang et al., 2013). These two species are two of the most successful invasive species around the world and have been treated as an international pest fish (Gozlan et al., 2010; Patimar et al., 2008). The simple age structure of these two species was usually considered as one of the major reasons the species became dominant within a very short time in many new regions (Gozlan et al., 2010; Wang et al., 2013).

This reason also seems likely for T. swinhonis in the lakes along the middle and lower reaches of the Yangtze River basin.

In terms of growth, the results of VBGMs from the present study indicated that there were some differences in the growth curves of $T$. swinhonis in different lakes and these differences are mainly reflected in the average asymptotic total length $\left(L_{\infty}\right)$ as the growth constants $(K)$ were the same $\left(1.20\right.$ year $\left.^{-1}\right)$ in all the three lakes. Moreover, the growth parameters $\left(L_{\infty}, K\right.$ and $\left.\phi^{\prime}\right)$ obtained by the current study were much larger than the values reported by Ye et al. (2014) in Niushan Lake, China $\left(L_{\infty}=145 \mathrm{~mm}, K=0.66\right.$ year $\left.^{-1}, \phi^{\prime}=4.14\right)$ (Table 3). Many studies have documented differences in growth of a given species in different geographical areas (SternPirlot 
$316 \&$ Wolff, 2006; Vakily, 1992), and the differences might be due to the heterogeneity of habitat

317 and diversity of genetics (Parra et al., 2009; Pauly, 1986; Wootton, 1998).

318

319 Mortality and fisheries status

320

321

322

323

324

325

326

327

328

329

330

331

332

333

334

335

336

Mortality rates are a measure of describing the rate at which fish disappear from a population and are critical parameters in formulating sustainable fishing regulations (Ogle, 2016). In view of this, we estimated the total mortality rates $(Z)$, natural mortality rates $(M)$ and fishing mortality rates $(F)$ of $T$. swinhonis in the three shallow lakes along the middle and lower reaches of the Yangtze River basin. We present the first evaluation of exploitation rate $(E)$.

Catch curve analysis showed that the values of $Z$ for $T$. swinhonis were 5.82 (in BDT), 5.50 (in $\mathrm{SJH}$ ) and 4.55 (in $\mathrm{KLH}$ ) year-1, indicating a decreasing trend with increasing longitude. We noted that the values of $Z$ estimated in the present study were much bigger than Ye et al. (2014) in Niushan lake, China $\left(Z=2.92\right.$ year- $\left.^{-1}\right)$. The differences of functions of these lakes and the fishing effort may explain these differences (Table 4).

Values for $M$ were similar between lakes: $\mathrm{BDT}=1.89, \mathrm{SJH}=1.87$ and $\mathrm{KLH}=1.75$. These values were slightly higher than the findings of Ye et al. (2014) in Niushan Lake, China ( $M=$ 1.35). Meanwhile, the values of $M / K$ ratio in our study were 1.58 (in BDT), 1.56 (in SJH) and 1.46 (in KLH), within the interval of 1.12-2.50 for most fish (Pauly, 1980), indicating our estimate of $M$ is reasonable. However, Pauly (1980) also postulated that $M$ should be in the range of 0.2-0.3, indicating T. swinhonis in the region of the Yangtze River basin was characterized with relatively high $M$, not uncommon for short-lived species. 
337 The fishing mortality rate $(F)$ in BDT, SJH and KLH were 3.93, 3.63 and 2.80 year $^{-1}$, values

338 that were much higher than those found by Ye et al. (2014) in Niushan Lake, China $(F=1.57)$.

339 High values of $F$ at all sites were likely related to the morphological characteristics (barbs on the

340 dorsal fin of $T$. swinhonis made them more susceptible to capture by multi-gillnets than other

341 species). Certainly, the difference between the present study and previous work conducted by $Y e$

342 et al. (2014) may be explained by the gear employed. We used the float multi-gillnets in the

343 present study which targeted the preferred water layer (pelagic) of $T$. swinhonis while sink multi-

344 gillnets was used by Ye et al. (2014) in Niushan Lake, China targeted the bottom.

345 Based on estimates of $F$ and $Z$, the exploitation rates $(E)$ in BDT, SJH and KLH were 0.68,

3460.66 and 0.62 , respectively. According to the rule of thumb (when $E$ was more than 0.5 , the fish

347 stock was undergoing overfishing) proposed by Gulland (1965), we found that the stocks in the

348 present study areas had been overfished slightly, which should be considered by fisheries

349 managers in the future.

350

\section{Recruitment time and pattern}

352 Recruitment is a very important period in a fish's life history and can be expressed as the number

353 of fish that reach a certain age or length, which can give us an insight into the future viability of

354 a fish population or predict the possible harvest from the population (Ogle, 2016).

355 The spawning time and pattern of $T$. swinhonis in the present study was identical at all sites

356 and annual recruitment consisted of two seasonal pulses (batch spawning) which occurred

357 between months of March to September. Long recruitment time and strong reproductive ability 
358 (LS Liu, 2017, unpublished data) may be the main reasons why the species became dominant in

359 these lakes. Despite close agreement with annual changes of gonadosomatic index (GSI) and 360 distributions of egg size (LS Liu, 2017, unpublished data), the results in the present study are not 361 consistent with $\mathrm{Ye}$ et al. (2014), who found the annual recruitment only consisted of one plus 362 (single spawning) which occurred between April and August. This is an important topic for 363 future research.

\section{CONCLUSIONS}

366

367

368

369

370

371

372

373

374 375

376

377 378

This study is the first attempt to elucidate the mechanism of population outbreaks of T. swinhonis in the lakes along the middle and lower reaches of the Yangtze River basin based on novel and comprehensive biological data. Current results showed that, like many other freshwater fishes, brief generation-time, fast growth rate, relatively high natural mortality rates and strong reproductive capacity ( $r$-strategies) may be the main causes that this fish became the most dominant fish species in many lakes of China. Thus, to control the population of $T$. swinhonis, to catch it moderately before its spawning season or release predator fish discreetly is proposed (Ye et al., 2007). Certainly, more field investigations should be conducted on this species in the future, especially on the reproductive biology and population dynamics of this species.

\section{ACKNOWLEDGMENTS}

We are grateful to Ms. Jin Yuan, Mr. Mantang Xiong, Mr. Zhan Mai, Mr. Lisheng Liu and Mr. Xinnian Chen for their assistance in the field sampling. We would also like to give our sincere 
379 appreciations to two anonymous referees for their valuable comments and suggestions, leading 380 the huge improvement of the earlier manuscript of this paper.

381

382

383

384

385

386

387

388

389

390

391

392

393

394

395

396

397

398

399

\section{REFERENCES}

Afrooz E, Gholamreza E, and Seyed A. 2014. Length-weight relationship and Fulton's condition factor of Carasobarbus luteus (Heckel, 1843) in Hoor Al-azim wetland. Journal of Ecology and the Natural Environment 6:238-243. DOI 10.5897/JENE2014.0449.

Appelberg M, Berger H, Hesthagen T, Kleiven E, Kurkilahti M, Raitaniemi J, and Rask M. 1995. DEVELOPMENT AND INTERCALIBRATION OF METHODS IN NORDIC FRESHWATER FISH MONITORING. Water, Air, and Soil Pollution 85:401-406. DOI 10.1007/bf00476862.

Beverton R, and Holt S. 1957. On the dynamics of exploited fish populations. London: Chapman \& Hall.

Cao W, Zhang G, Ma J, and Yu D. 1991. Preliminary studies on the phenomenon of size diminution of the fish resources in Lake Honghu (Honghu Research Group, Institute of Hydrobiology, Academia Sinica, ed.). Beijing: China Ocean Press. (In Chinese).

Cren E. 1951. THE LENGTH-WEIGHT RELATIONSHIP AND SEASONAL CYCLE IN GONAD WEIGHT AND CONDITION IN THE PERCH (PERCA FLUVIATILIS). Journal of Animal Ecology 20 (2):201-219.

Da C. 2015. Evaluation of measurement errors of temperature and relative humidity from HOBO data logger under different conditions of exposure to solar radiation. Environmental 
400

401

402

403

404

405

406

407

408

409

410

411

412

413

414

Monitoring \& Assessment 187 (5):236. DOI 10.1007/s10661-015-4458-x.

Dai X, Li W, Fan Y, and Tian S. 2015. Complete mitochondrial genome of Toxabramis swinhonis (Cypriniformes, Cyprinidae). Mitochondrial DNA Part A 28:56-57. DOI 10.3109/19401736.2015.1110796.

Dalton H, Wood B, Dickey J, and Torrey S. 2016. Validation of HOBO Pendant ${ }^{\circledR}$ data loggers for automated step detection in two age classes of male turkeys: growers and finishers. Applied Animal Behaviour Science 176:63-69. DOI 10.1016/j.applanim.2015.12.005.

Elliott J. 1983. Fish Stock Assessment. A Manual of Basic Methods by J. A. Gulland. Biometrics 40 (3).

Froese R. 2006. Cube law, condition factor and weight-length relationships: history, metaanalysis and recommendations. Journal of Applied Ichthyology 22:241-253. DOI 10.1111/j.1439-0426.2006.00805.x.

Gayanilo F, Sparre P, and Pauly D. 2005. FAO-ICLARM Stock Assessment Tools (FISAT-II) User's Guide. Roman: Computerized Information Series, FAO.

Ge K, Zhong J, and Tang J. 2009. Primarily Study on Species Composition of Fish Larvae and Juveniles in Elver Net of Yangtze River Estuary. Journal of Zhejiang Ocean University (Natural Science) 28:6. DOI 1008-830X(2009)03-0298-05. (In Chinese).

Gozlan R, Andreou D, Asaeda T, Beyer K, Bouhadad R, Burnard D, Caiola N, Cakic P, Djikanovic V, and Esmaeili H. 2010. Pan-continental invasion of Pseudorasbora parva: towards a better understanding of freshwater fish invasions. Fish \& Fisheries 11:315-340. 
421

422

423

424

425

426

427

428

429

430

431

432

433

434

435

436

437

438

439

440

441

Gulland J. 1965. Estimation of mortality rates. Annex to Arctic fisheries working group report.

Guo Z, Liu J, Sovan L, Li Z, Zhu F, Tang J, and Julien C. 2016. Age, growth and population dynamics of two congeneric and invasive gobies, Rhinogobius giurinus and R. Cliffordpopei (Actinopterygii, Gobiidae) in a plateau lake, southwestern China. Hydrobiologia 763(1):6979. DOI 10.1007/s10750-015-2361-7.

Hilborn R, and Walters C. 1992. Quantitative Fisheries Stock Assessment. London: Chapman and Hall.

Hollyman, P. 2017. Age, growth and reproductive assessment of the whelk, Buccinum undatum, in coastal shelf seas. D. Phil. Thesis, Prifysgol Bangor University.

Koutrakis E, and Tsikliras A. 2003. Length-weight relationships of fishes from three northern Aegean estuarine systems (Greece). Journal of Applied Ichthyology 19:258-260. DOI 10.1046/j.1439-0426.2003.00456.x.

Li D, Wu X, Xie Z, and Lian Y. 1988. Role of minnows in the fish-farming reservoirs and control of their poupulations. Acta Ecologica Sinica 8:304-310. (In Chinese).

Li W, Zhang T, and Li Z. 2010. Spatial distribution and abundance of small fishes in XiaosihaiLake, a shallow lake along the Changjiang (Yangtze) River, China. Chinese Jornal of Oceanology and Limnology 28 (3):470-477. DOI 10.1007/s00343-010-9082-6.

Li Z. 2004. Adjustment of fisheries structure and resources in lakes along the middle and lower reaches of the Yangtze River. Resource and Environment 11:74-77. (In Chinese).

Li W, J. Hicks B, Lin M, Guo C, Zhang T, Liu J, Li Z, and A. Beauchamp D. 2018. Impacts of hatchery-reared mandarin fish Siniperca chuatsi stocking on wild fish community and 
442

443

444

445

446

447

448

449

450

451

452

453

454

455

456

457

458

459

460

461

462

water quality in a shallow Yangtze lake. Scientific reports 8:1-11. DOI: 10.1038/s41598-01829758-Z.

Liu E, Liu Z, Chen W, Bao C, and Wan Q. 2005. A Study on the Change of Lake Anchovy (Coilia ectenes taihuensis Yen et Lin) Catches and Its Mutual Relationship to the Biological Environment in Lake Taihu. Journal of Lake Science 17 (4):340-345. (In Chinese).

Liu J, and He B. 1992. Cultivation of the Chinese freshwater fishes. Beijing, China: Science Press. (In Chinese).

Mao Z, Gu X, Zeng Q, Zhou L, Wang X, Wu L, Cao P, and Sun M. 2011. Community structure and diversity of fish in Lake Taihu. Chinese Journal of Ecology 30 (12):2836-2842. (In Chinese).

Mirzaei M, Yasin Z, and Hwai A. 2014. Length-weight relationship, growth and mortality of Anadara granosa in Penang Island, Malaysia: An approach using length-frequency data sets. Journal of the Marine Biological Association of the United Kingdom 95:381-390. DOI $10.1007 / \mathrm{S} 0025315414001337$.

Moreau J, and Cuende F. 1991. On improving the resolution of the recruitment patterns of fishes. Fishbyte 9 (1):45-46.

Narejo N, Mastoi A, Lashari P, Abid M, Laghari M, and Mahesar H. 2009. Age determination of a carp, Labeo calbasu (Hamilton) from Keenjhar Lake (District: Thatta), Sindh, Pakistan. Sindh University Research Journal 41(1):83-86.

O'Brien C. 2012. Modelling and Quantitative Methods in Fisheries, Second Edition by Malcolm Haddon. International Statistical Review 80(1):201-202. DOI 10.1111/j.1751- 
463

464

465

466

467

468

469

470

471

472

473

474

475

476

477

478

479

480

481

482

483

5823.2012.00179_26.x.

Ogle D. 2016. Introductory Fisheries Analyses with R. USA: CRC Press.

Parra I, Almodóvar A, Nicola G, and Elvira B. 2009. Latitudinal and altitudinal growth patterns of brown trout Salmo trutta at different spatial scales. Journal of Fish Biology 74:2355-2373. DOI 10.1111/j.1095-8649.2009.02249.x.

Patimar R, Abdoli A, and Kiabi B. 2008. Biological characteristics of the introduced sawbelly, Hemiculter leucisculus (Basilewski, 1855), in three wetlands of northern Iran: Alma-Gol, Adji-Gol and Ala-Gol. Journal of Applied Ichthyology 24(5):617-620. DOI 10.1111/j.14390426.2008.01080.x.

Pauly D. 1980. On the interrelationships between natural mortality, growth parameters, and mean environmental temperature in 175 fish stocks. Ices Journal of Marine Science 39(2):175-192.

Pauly D. 1983. Some simple methods for the the assessment of tropical fish stock. Rome: Food and Agriculture Organization of the United Nations.

Pauly D. 1986. Fish population dynamics in tropical waters: A manual for use with programmable calculators. Fisheries Research 4(2):18:171-173. DOI 10.1016/0165-

\section{6(86)90044-5.}

Pauly D, and Munro J. 1984. Once more on the comparison of growth in fish and invertebrates. Fishbyte, Newsletter of the Network of Tropical Fisheries Scientists 2(1):21.

Peter B. 1980. Life history patterns in marine fishes and their consequences for fisheries management. Fishery bulletin 78(1):1-12. 
484

485

486

487

488

489

490

491

492

493

494

495

496

497

498

499

500

501

502

503

504

Ricker. 1975. Computation and interpretation of biological statistics of fish populations. Bulletin of the Fisheries Research Board of Canada (191):401.

Sparre P, and Venema S. 1998. Introduction to tropical fish stock assessment. Rome: Food and Agriculture Organization of the United Nations.

Steinmetz B, and Müller R. 1991. An atlas of fish scales and other bony structures used for age determination: non-salmonid species found in European fresh waters. UK: Samara Publishing, Cardigan.

SternPirlot A, and Wolff M. 2006. Population dynamics and fisheries potential of Anadara tuberculosa (Bivalvia: Arcidae) along the Pacific coast of Costa Rica. Revista De Biologia Tropical 54(Suppl 1):87-99.

Taiwo O. 2010. LENGTH FREQUENCY DISTRIBUTION AND LENGTH-WEIGHT RELATIONSHIP OF Schilbe mystus FROM LEKKI LAGOON IN LAGOS, NIGERIA. Journal of Agricultural and Veterinary Sciences 2:63-69.

Von Bertalanffy L. 1938. A quantitative theory of organic growth (inquiries on growth laws. 11.). Human Biology 10(2): 181-213.

Vakily J. 1992. Determination and comparison of bivalve growth, with emphasis on Thailand and other tropical areas. Manila: the International Center for Living Aquatic Resources Management.

Wang T, Wang H, Sun G, Huang D, and Shen J. 2012. Length-weight and length-length relationships for some Yangtze River fishes in Tian-e-zhou Oxbow, China. Journal of Applied Ichthyology 28:660-662. DOI 10.1111/j.1439-0426.2012.01971.x. 
505

506

507

508

509

510

511

512

513

514

515

516

517

518

519

520

521

522

523

524

525

Wang T, Huang D, Zhao Y, Wang H, Hu S, and Shen J. 2013. Age, growth and mortality of invasive sharpbelly, Hemiculter leucisculus (Basilewski, 1855) in Erhai Lake, China. Journal of Applied Ichthyology 29:1279-1285. DOI 10.1111/jai.12287.

Wells R, Kohin S, Teo S, Snodgrass O, and Uosaki K. 2013. Age and growth of North Pacific albacore (Thunnus alalunga): Implications for stock assessment. Fisheries Research 147:5562. DOI 10.1016/j.fishres.2013.05.001.

Wootton R. 1998. Ecology of teleost fishes, second edition. Boston: Kluwer Academic Publishers.

Xie S, Cui Y, and Li Z. 2001a. Dietary-morphological relationships of fishes in Liangzi Lake, China. Journal of Fish Biology 58:1714-1729. DOI 10.1006/jfbi.2001.1580.

Xie S, Cui Y, and Li Z. 2001b. Small fish communities in two regions of the Liangzi Lake, China, with or without submersed macrophytes. Journal of Applied Ichthyology 17:89-92.

Ye S, Moreau J, Zeng W, Zhang T, Liu J, and Li Z. 2014. Growth and mortality of two small fishes, Toxabramis swinhonis Günther, 1873 and Hyporhamphus intermedius ( Cantor, 1842), in a Yangtze shallow lake ( China) assessed by length frequency analysis. Journal of Applied Ichthyology 30:479-484. DOI 10.1111/jai.12405.

Ye S, Li Z, Feng G, and Cao W. 2007. Length-Weight Relationships for Thirty Fish Species in Lake Niushan, a Shallow Macrophytic Yangtze Lake in China. Asian Fisheries Science 20:217-226.

Ye S, Li Z, Lek-Ang S, Feng G, Lek S, and Cao W. 2006. Community structure of small fishes in a shallow macrophytic lake (Niushan Lake) along the middle reach of the Yangtze River, 
526 China. Aquatic Living Resources 19(4): 345-359.

527 Zhang T, and Li Z. 2002. Age, Growth, and Reproduction of the Bitterling (Paracheilognatus 528 imberbis) in a Shallow Chinese Lake. Journal of Freshwater Ecology 17(4):501-505.

529 Zhang T. 2005. Life history strategies, trophic patterns and community structure in the fishes of 530 lake biandantang. In Institute of Hydrobiology, Chinese Academy of Science, p. 248. Wuhan, China: University of Chinese Academy of Science. (In Chinese). 
Figure 1

Map of the study area and locations of the three sampling sites for $T$. swinhonis (in the middle and lower reaches of Yangtze River basin, China). BDT, SJH and KLH are the abbreviations of Biandantang Lake, Shengjin Lake and Kuilei Lake.

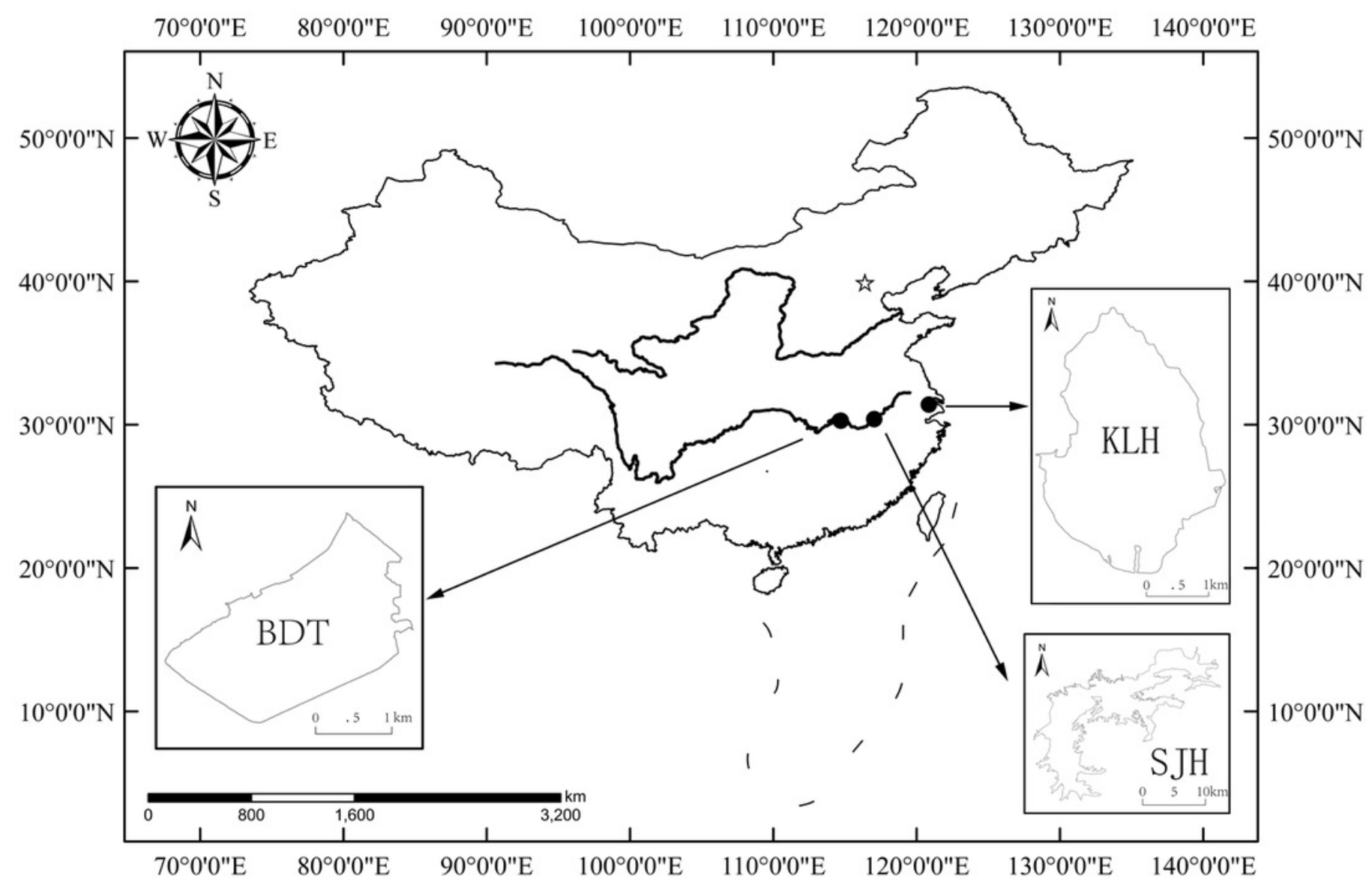


Figure 2

Annual total length frequency distribution of $T$. swinhonis in (A) BDT, (B) SJH and (C) KLH.
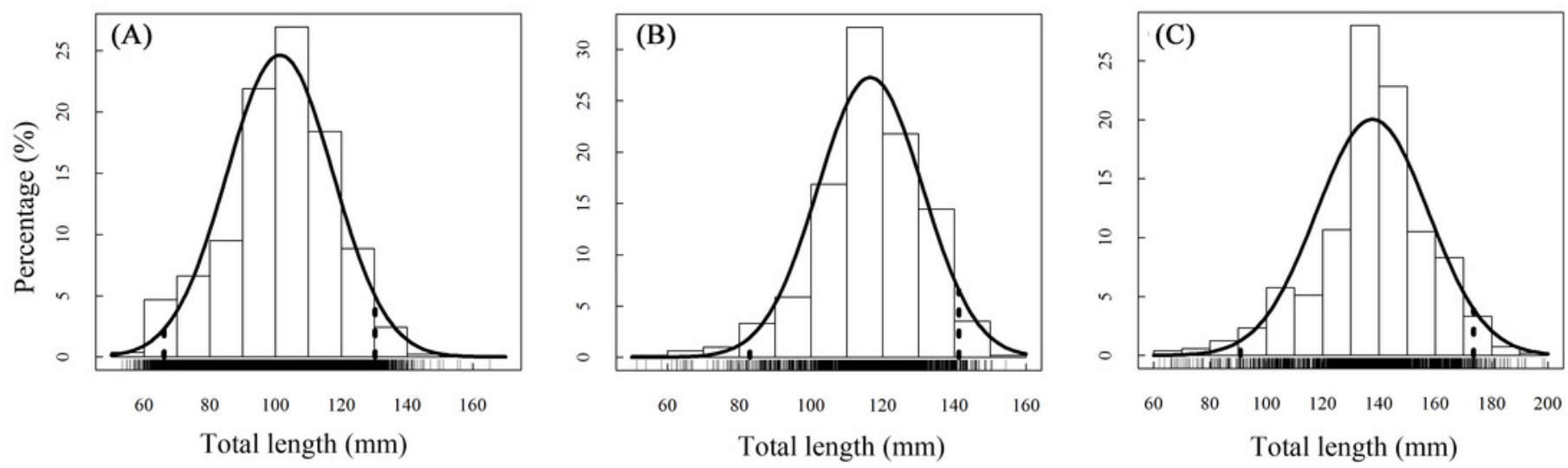
Figure 3

Boxplot (horizontal line within box: median; boundaries of the box: first and third quartiles; bars: lower and upper inner fences; circles: outliers) about Kruskal-Wallis test in the total length (L) of $T$. swinhonis at different sampling sites.

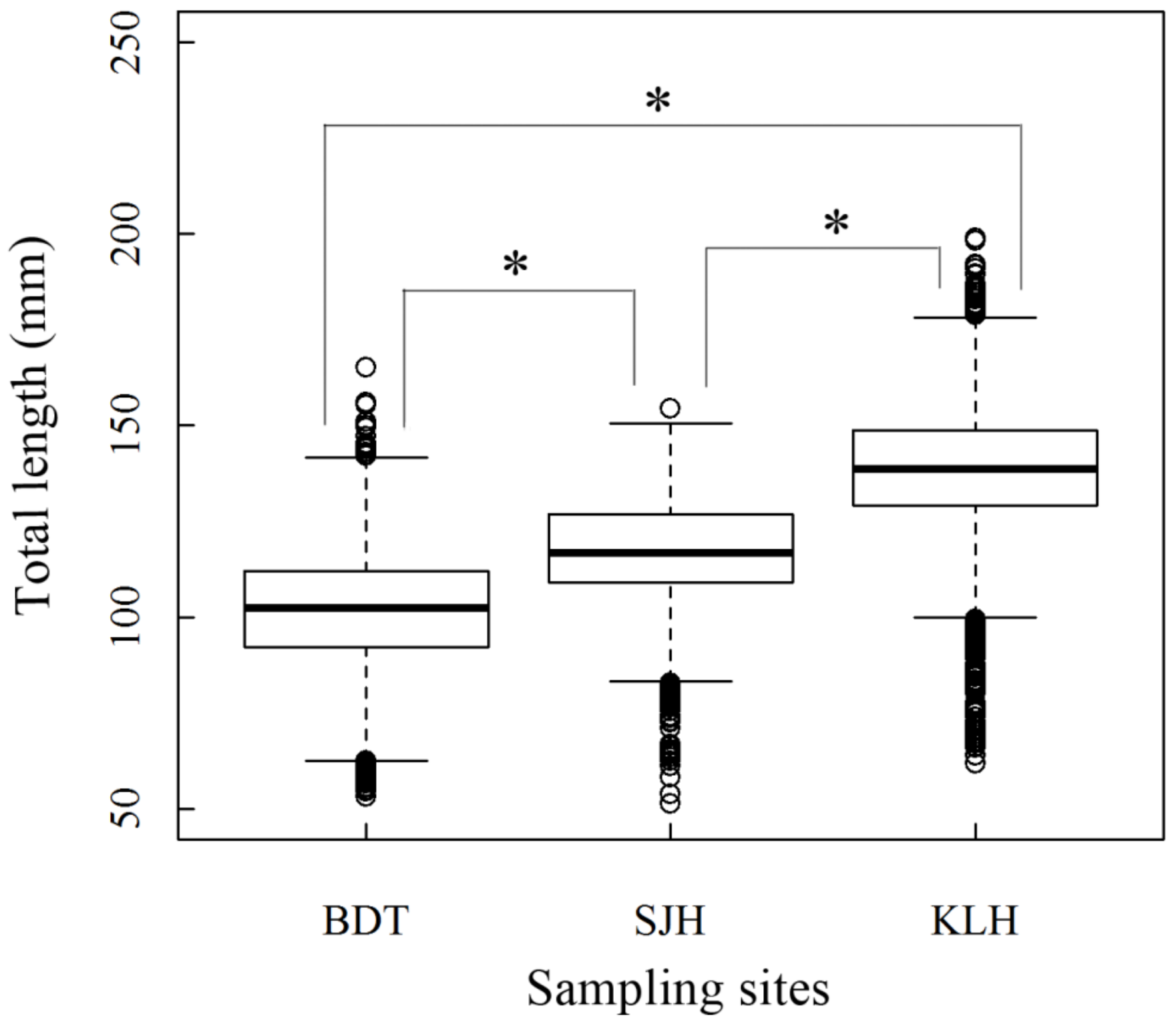


Figure 4

The scales of $T$. swinhonis from BDT Lake with (a), (b), (c) and (d) corresponded with $0^{+}$, $1^{+}, 2^{+}$and $3^{+}$years, respectively. Blue dots represented the annuli.

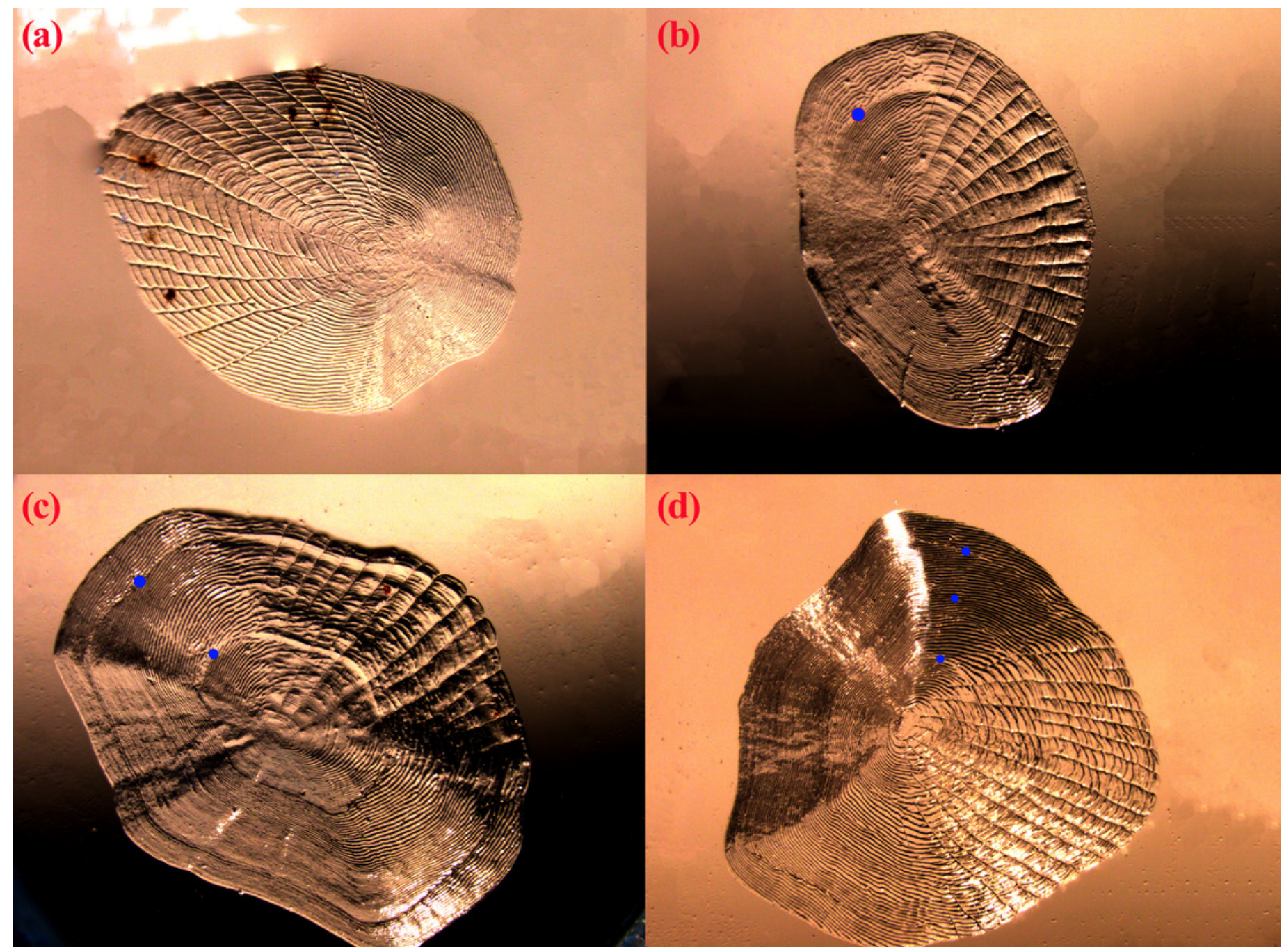


Figure 5

Total length-weight relationships of T. swinhonis in (a) Biandantang Lake, (b) Shengjin Lake and (c) Kuilei Lake.

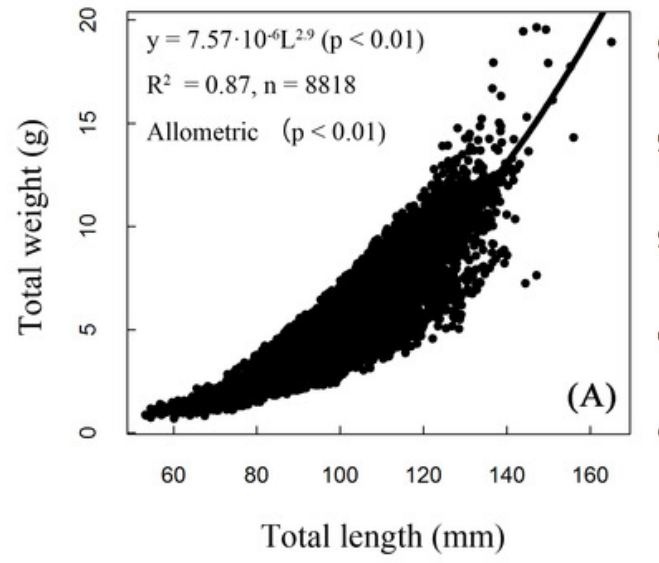

Total length (mm)

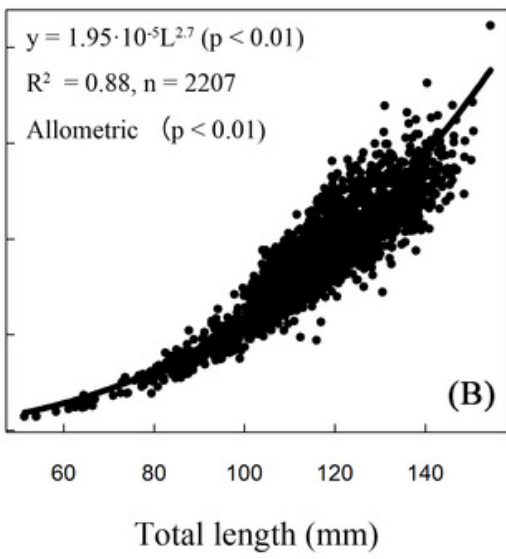

(B)

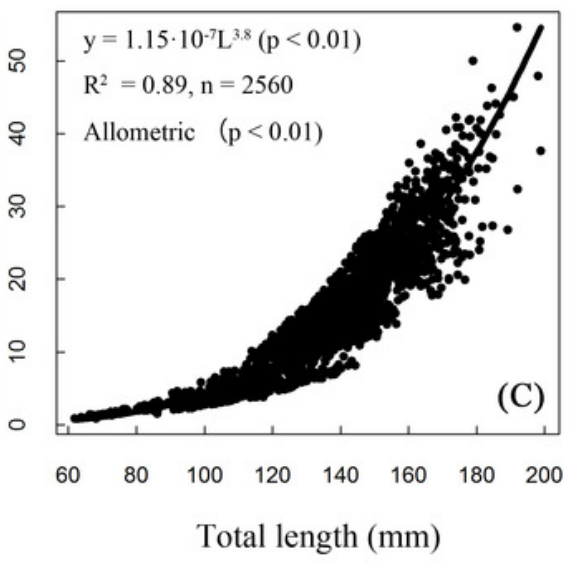


Figure 6

The von Bertalanffy growth curves of $T$. swinhonisin in (a) Biandantang Lake, (b) Shengjin Lake and (c) Kuilei Lake as superimposed on the length-frequency histograms. The different solid lines (blue) corresponded with different cohorts. 

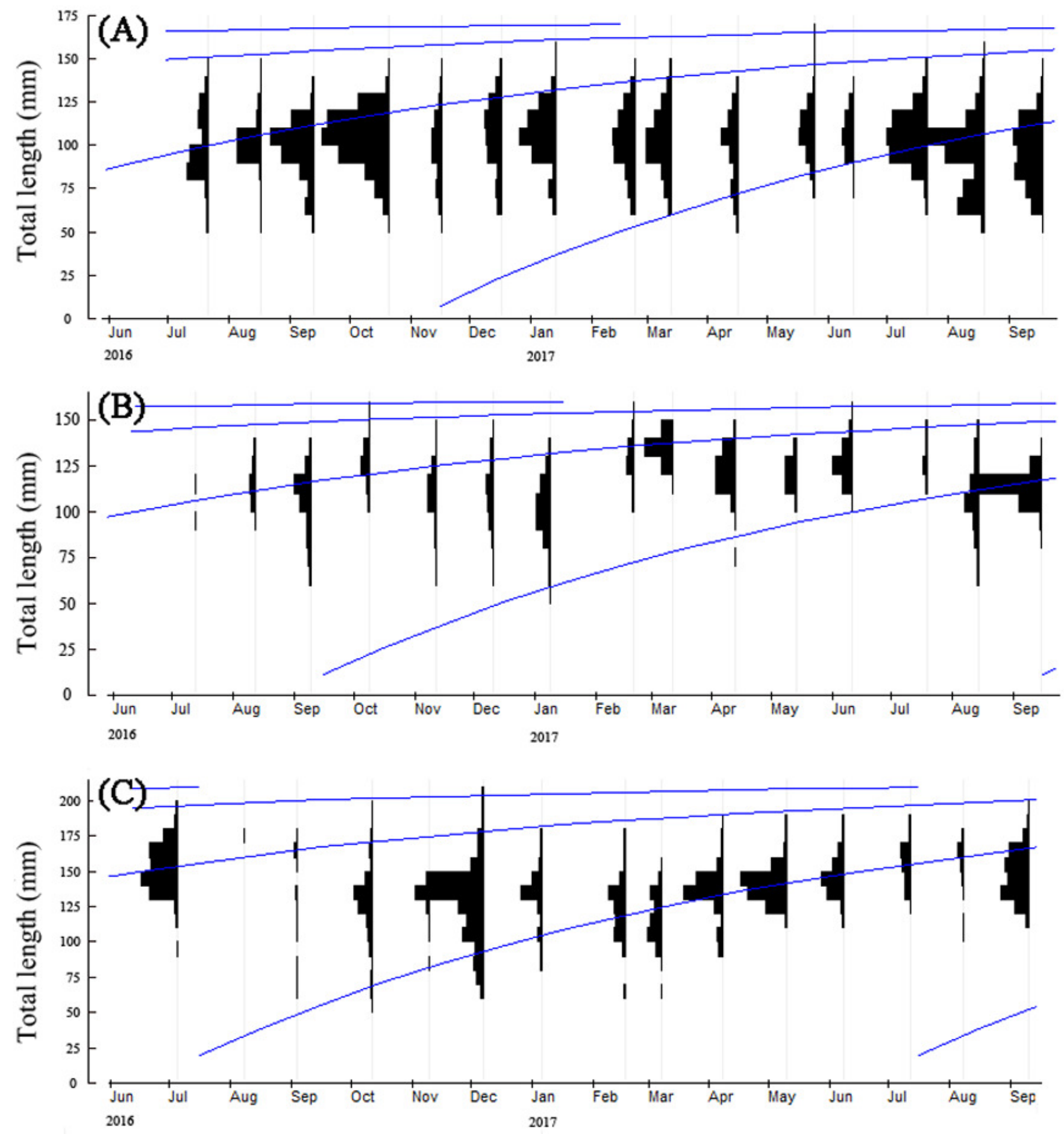

Month 
Figure 7

Length-converted catch curves used to estimate total mortality $(Z)$ of $T$. swinhonis collected from (a) BDT, (b) SJH and (c) KLH along the middle and lower reaches of the Yangtze River basin, China.

(A)

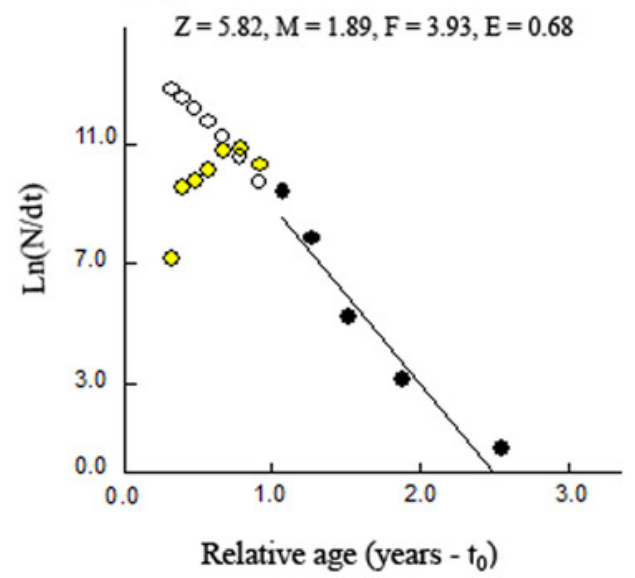

(B)

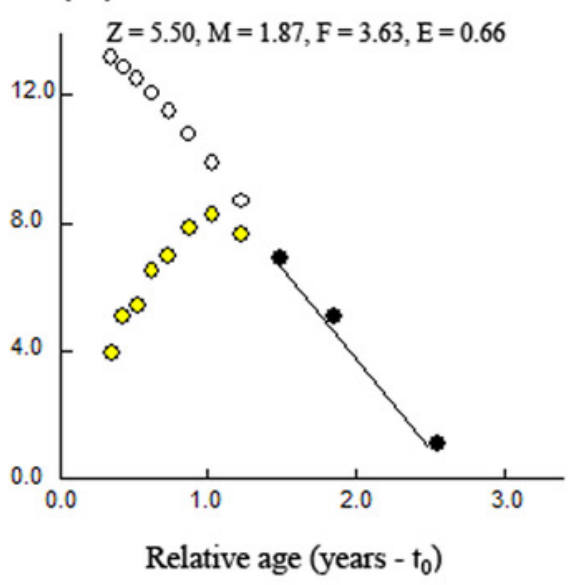

(C)

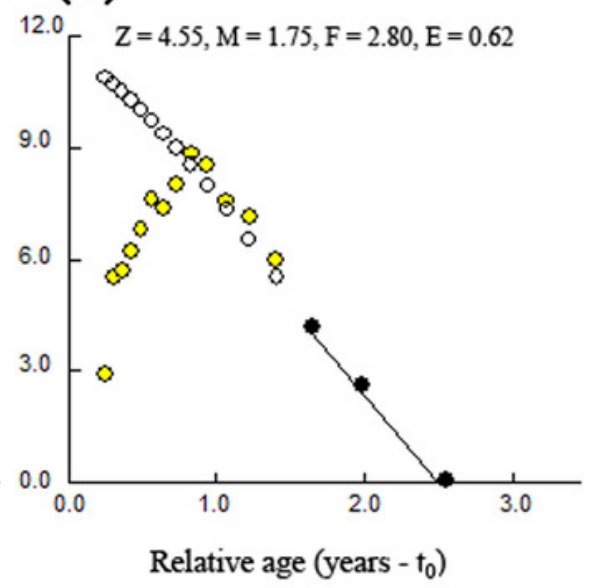


Figure 8

Annual relative recruitment patterns of $T$. swinhonis in (a) BDT, (b) SJH and (c) KLH.
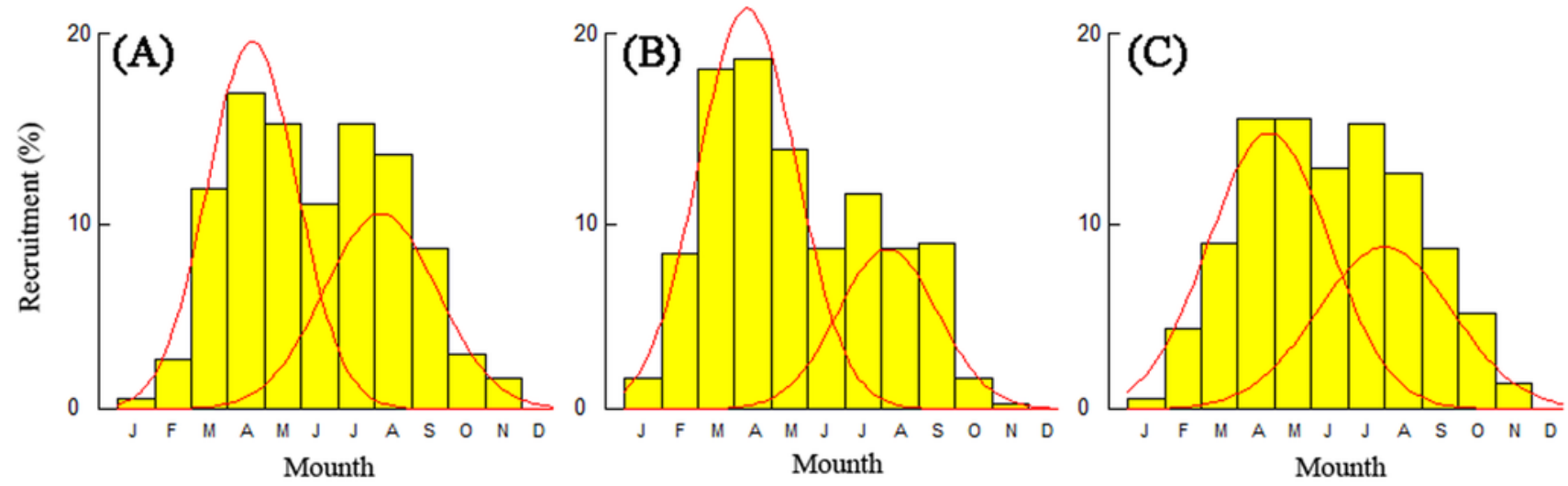


\section{Table $\mathbf{1}$ (on next page)}

Mean observed length ( $\mathrm{mm}$ )-at-age for $T$. swinhonis fish from Biandantang Lake, Shengjin Lake, and Kuilei Lake. 


\begin{tabular}{|c|c|c|c|c|c|c|c|c|c|}
\hline \multirow[b]{2}{*}{ Age } & \multicolumn{3}{|c|}{ Biandantang Lake } & \multicolumn{3}{|c|}{ Shengjin Lake } & \multicolumn{3}{|c|}{ Kuilei Lake } \\
\hline & $\begin{array}{c}\text { Mean } \pm \text { S.E. } \\
(\mathrm{mm})\end{array}$ & $\mathrm{n}$ & $\begin{array}{c}\text { Percentage } \\
\text { (\%) }\end{array}$ & $\begin{array}{c}\text { Mean } \pm \text { S.E. } \\
(\mathrm{mm})\end{array}$ & $\mathrm{n}$ & $\begin{array}{c}\text { Percentage } \\
(\%)\end{array}$ & $\begin{array}{c}\text { Mean } \pm \text { S.E. } \\
(\mathrm{mm})\end{array}$ & $\mathrm{n}$ & $\begin{array}{c}\text { Percentage } \\
(\%)\end{array}$ \\
\hline 1 & $102.99 \pm 1.01$ & 307 & 74.15 & $113.85 \pm 0.87$ & 316 & 65.83 & $131.19 \pm 1.09$ & 298 & 45.43 \\
\hline 2 & $111.05 \pm 1.28$ & 99 & 23.92 & $127.97 \pm 0.79$ & 157 & 32.71 & $153.73 \pm 0.74$ & 351 & 53.51 \\
\hline 3 & $116.91 \pm 7.16$ & 6 & 1.45 & $131.46 \pm 2.62$ & 7 & 1.46 & $166.60 \pm 8.24$ & 7 & 1.06 \\
\hline 4 & $131.91 \pm 13.68$ & 2 & 0.48 & NA & NA & 0.00 & NA & NA & 0.00 \\
\hline
\end{tabular}

1 NA: not available; $n$ : the number of specimen; S.E.: standard error. 
Table 2 (on next page)

Summary of parameters of length-weight relationships of $T$. swinhonis. 


\begin{tabular}{|c|c|c|c|c|c|c|}
\hline \multirow{2}{*}{ Study area (source) } & \multicolumn{2}{|c|}{ Total length $(\mathrm{cm})$} & \multicolumn{3}{|c|}{ parameters } & \multirow{2}{*}{$\mathrm{n}$} \\
\hline & Minimum & Maximum & a & $\mathrm{b}$ & $r^{2}$ & \\
\hline Poyang Lake, China (Changjiang ichthyography, 1974) ${ }^{\mathrm{bc} *}$ & 5.3 & 11.1 & NA & NA & NA & 10 \\
\hline Dongting Lake, China (The fishes of Hunan, 1980) $)^{\mathrm{bc} *}$ & 8.7 & 12.3 & NA & NA & NA & 10 \\
\hline Liangzi Lake, China (The fishes of Hubei, 1986) ${ }^{\mathrm{bc} *}$ & 5.3 & 10.5 & NA & NA & NA & 10 \\
\hline Bashan and Zhangze reservoir, China (Li et al.,1988)* & NA & 13.4 & NA & NA & NA & 135 \\
\hline Hunan, hubei, hebei and sichuan China (FAUNA SINICA, 1998) ${ }^{\mathrm{bc} *}$ & 7.2 & 11.8 & NA & NA & NA & 23 \\
\hline Biandantang Lake, China (Zhang et al., 2005) ${ }^{\mathrm{d} *}$ & 3.2 & 9.5 & 0.0098 & 3.037 & 0.98 & 61 \\
\hline Niushan Lake, China (Feng et al., 2006)* & 2.4 & 9.5 & NA & NA & NA & 416 \\
\hline Niushan Lake, China (Ye et al., 2007)* & 5.3 & 12.1 & 0.0061 & 2.845 & 0.897 & 289 \\
\hline The estuary of the Yangtze River, China (Ge et al., 2009) ${ }^{\mathrm{b} *}$ & 0.4 & 2.5 & NA & NA & NA & 91849 \\
\hline Niushan Lake, China (Zhang et al., 2012)* & 8.4 & 9.4 & NA & NA & NA & 2 \\
\hline Tian-e-zhou Oxbow, China (Wang et al., 2012) ${ }^{\mathrm{bc}}$ & 5.0 & 9.3 & 0.0060 & 3.220 & 0.955 & 103 \\
\hline Niushan Lake, China (Ye et al., 2014) & 4.2 & 12.8 & NA & NA & NA & 2132 \\
\hline
\end{tabular}




\begin{tabular}{|c|c|c|c|c|c|c|}
\hline Biandantang Lake, China (the present study) ${ }^{\mathrm{a} *}$ & 5.3 & 16.5 & 0.0061 & 2.906 & 0.870 & 8818 \\
\hline Shengjin Lake, China (the present study) ${ }^{\mathrm{a} *}$ & 5.1 & 15.4 & 0.0106 & 2.734 & 0.878 & 2207 \\
\hline Kuilei Lake, China (the present study) ${ }^{\mathrm{a} *}$ & 6.2 & 19.9 & 0.0007 & 3.775 & 0.886 & 2560 \\
\hline
\end{tabular}

$1 \mathrm{n}$ : the number of specimen; a: intercept; $\mathrm{b}$ : regression slop; $r^{2}$ : coefficient of determination; NA: not available.

2 aNew records of maximum total length in FishBase.

3 bStudies with very narrow total length range.

$4 \quad$ 'Small number of specimens.

5 dStandard length was being used in the study.

$6 \quad$ "Materials out of FishBase. 


\section{Table 3 (on next page)}

Summary of population characteristics of $T$. swinhonis in different geographical areas. 


\begin{tabular}{|c|c|c|c|c|c|c|c|c|c|}
\hline Study area & Aging structure & $L_{\infty}(\mathrm{mm})$ & $K\left(\right.$ year $\left.^{-1}\right)$ & $t_{0}($ year $)$ & $\phi^{\prime}$ & Age range (year) & $\mathrm{R}_{\mathrm{n}}$ & $\mathrm{n}$ & First author, year \\
\hline \multicolumn{10}{|l|}{ Bashan reservoir, China ${ }^{1}$} \\
\hline & Scales & NA & NA & NA & NA & $1-6$ & NA & 134 & Li (1988) \\
\hline \multicolumn{10}{|l|}{ Zhangze reservoir, China $^{1}$} \\
\hline Niushan Lake, China & NA & 145.00 & 0.66 & 0.30 & 4.14 & NA & 0.38 & 2132 & Ye (2014) \\
\hline Biandantang Lake, China & Scales & 173.25 & 1.20 & -1.09 & 4.56 & $1-4$ & 0.21 & 8818 & The present study \\
\hline Shengjin Lake, China & Scales & 162.75 & 1.20 & -1.08 & 4.52 & $1-3$ & 0.29 & 2207 & The present study \\
\hline Kuilei Lake, China & Scales & 215.25 & 1.20 & -1.12 & 4.75 & $1-3$ & 0.24 & 2560 & The present study \\
\hline
\end{tabular}

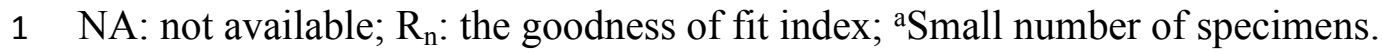




\section{Table 4(on next page)}

Estimated mortality rates of $T$. swinhonis derived from different areas. 


\begin{tabular}{cccc}
\hline \multicolumn{1}{c}{ Study areas (year) } & $Z\left(\right.$ year $\left.^{-1}\right)$ & $M\left(\right.$ year $\left.^{-1}\right)$ & $F\left(\right.$ year $\left.^{-1}\right)$ \\
\hline Biandantang Lake, China (the present study) $)^{\mathrm{ad}}$ & 5.82 & 1.89 & 3.93 \\
Shengjin Lake, China (the present study) & & & 1.87 \\
Kuilei Lake, China (the present study) & 5.50 & 1.75 & 2.83 \\
Niushan Lake, China $(2014)^{\mathrm{c}}$ & 4.55 & 1.35 & 1.57 \\
\hline
\end{tabular}

1 aNational Wetland Park; ${ }^{b}$ Wellhead protection zone; ${ }^{\mathrm{c} A q u a c u l t u r e ~ b a s e ;}{ }^{\mathrm{d}}$ Having fishman. 